\title{
Jan Cronin and Simone Drichel, eds., Frameworks: Contemporary Criticism on Janet Frame
}

Peter Marsden

\section{(2) OpenEdition}

1 Journals

Electronic version

URL: https://journals.openedition.org/ces/8197

DOI: $10.4000 /$ ces.8197

ISSN: 2534-6695

Publisher

SEPC (Société d'études des pays du Commonwealth)

\section{Printed version}

Date of publication: 1 April 2011

Number of pages: 150-151

ISSN: 2270-0633

\section{Electronic reference}

Peter Marsden, "Jan Cronin and Simone Drichel, eds., Frameworks: Contemporary Criticism on Janet Frame", Commonwealth Essays and Studies [Online], 33.2 | 2011, Online since 18 November 2021, connection on 06 January 2022. URL: http://journals.openedition.org/ces/8197 ; DOI: https://doi.org/ $10.4000 /$ ces.8197

This text was automatically generated on 6 January 2022.

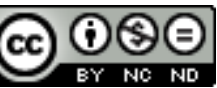

Commonwealth Essays and Studies is licensed under a Licence Creative Commons Attribution - Pas d'Utilisation Commerciale - Pas de Modification 4.0 International. 


\title{
Jan Cronin and Simone Drichel, eds., Frameworks: Contemporary Criticism on Janet Frame
}

\author{
Peter Marsden
}

\section{REFERENCES}

Jan Cronin and Simone Drichel, eds. Frameworks: Contemporary Criticism on Janet Frame. Amsterdam \& New York: Rodopi, Cross/Cultures 110, 2009. xxvii + 227 pages. ISBN 978 904202676 6. € 50/US\$ 68

1 Frameworks, "Frame-works" - get it? For all the critical acumen and gravitas in this new collection of essays, there is a whole lot of punning going on here too. Like Frame herself, the contributors to this valuable new compendium really love playing with words, not least with the author's name. For these Frameworkers, punning is no mere party pastime but the expression of a fundamental mindset (a framework, perhaps?), that can function as a creative epistemological instrument, opening up deep new insights along the lines of Gregory Ulmer's notion of the "puncept" (37). Not too many scholarly works can lead off with an upbeat announcement such as this: "These are exciting times for Janet Frame studies" (ix). What with the recent posthumous publication of two works by Frame (The Goose Bath, 2006 and Towards Another Summer, 2007) and a fictional work on Frame-the novel Gifted, (2010) in which Patrick Evans explores the literary life of 1950s Auckland centring around Frame and Sargeson Frame is indeed in the air. And Jan Cronin and Simone Drichel's critical anthology undeniably adds to the excitement.

2 The volume reviews the state of the art some three decades on from Jeanne Delbaere's critical anthology Bird, Hawk, Bogie: Essays on Janet Frame (1978) and nearly twenty years after the revised version, Ring of Fire: Essays on Janet Frame (1992). The new avenues of enquiry that have emerged in the interim are in several cases broadly aligned with 
postmodern-cum-poststructuralist theory, especially of the French school (Jean Baudrillard, Emmanuel Levinas). Clearly much thought has gone into the conception of the volume, which assembles nine individual essays by a judicious mix of "emerging and established" Frame scholars $(\mathrm{x})$ comprising, apart from the editors, Valérie Baisnée, Marc Delrez, Jennifer Lawn, Isabel Michell, Chris Prentice, Anna Smaill and Lydia Wevers. The topics range from existential thought through "playing with Freud" to language in Frame's poetry and "aesthetic and political violence." The book is divided into three sections, or "f/Frames": I "Meta-Critical Frame(s)"; II "Metaphysical Frame(s)"; and III "Beyond the Frame(s) of Representation," the whole volume bookended - framed - by the co-editors' own essays.

3 The collective approach adopted is "a universe away" from the biographical, socialrealist or nationalist readings in earlier accounts of Frame's work. The essays eschew cut-and-dried, unequivocal interpretation(s), preferring to accentuate the metaphysical and to focus on Frame as a "marginalized visionary" (xii). The hermeneutic leitmotif of the volume is formulated by Drichel in her closing essay on "Janet Frame's Ethical Transcendence": "Frame's texts are indeed very productively read not as puzzles to be solved but as irreducible enigmas" (207). Not for nothing does Cronin entitle her opening essay "Through a Glass Darkly: Reading the Enigmatic Frame."

4 The fact that half of the contributors are of New Zealand origin, with the other half coming from various European backgrounds, helps create diversity and variety of viewpoint. However, there is a remarkable degree of explicit consensus among the team as to the primus-inter-pares status due to one of their own number, Marc Delrez, who has produced "the most influential Frame study of recent times, namely Manifold Utopia (2002), which overhauled existing narratives of a postcolonial Frame, with their emphasis on settler liminalities and questions of indigeneity, to accommodate a metaphysical, humanist conception of Frame's 'postcoloniality"' (xv). Even beyond the illuminating and sensitive analyses of this volume, Frame's fiction continues to "resist containment" (182) - one of Delrez's tenets, invoked approvingly by his fellowcontributors. Frame's work "survives" Frameworks precisely because its makers have themselves resisted the temptation to try and contain Frame and her work within any single framework, their own book included. To some readers, dismissing the work of Patrick Evans as "notorious" twice on the same page (xi) might look like a case of overkill. But this is quite a minor blemish in this excellent, attractively presented volume, which looks destined to play its own seminal role in Frame studies for quite some time to come.

\section{AUTHORS}

\section{PETER MARSDEN}

Peter H. MARSDEN has retired from the Department of English Studies at RWTH Aachen University, Germany. His research interests embrace both linguistics and literature, with a 
particular focus on Australian and New Zealand poetry. His publications include essays on the oral tradition in Aboriginal and Maori writing as well as on Peter Bland, Peter Goldsworthy, Les Murray, Robert Sullivan and, most recently, Hone Tuwhare. 